\title{
研究論文
}

\section{要綱等の比較にみる京都における 初期土地区画整理事業の町割コンセプトの変遷}

Comparative Analysis among Technical Guidelines on the Concept of "Machi" Layout in Early Years of Kyoto City's Land Readjustment Projects

下村 泰史 ${ }^{*}$

Yasushi SHIMOMURA

\begin{abstract}
In Kyoto city readjustment areas in 1930's adopted street conscious method in "machi” layout. One "machi” was settled on both sides of a street. A street was the axis of a "machi". This structure is similar to the traditional "machi" layout in historical Kyoto city. This way of "machi” layout had gradually been given up in 1940's. In this paper we show some variation of technical guidelines about "machi" layout and compare them each other. Firstly we show the difference in naming concept of streets and "machi" between 1931's guideline and 1935's one, and the common idea about street conscious "machi" layout, and show the historical and traditional character of this concept. Secondly we show the character of 1935's guideline as not for all over the city but for northern area. Thirdly we show the clear difference between 1974's guideline and former ones. It have remarkable modern character.
\end{abstract}

Keywords : Kyoto, modern era, history of urban development, land readjustment, community, layout of town lots キーワード：京都，近代，歴史，土地区画整理，コミュニティ，町割

\section{1.はじめに}

大正時代以降, 京都市は環状道路の整備に併せ, 外縁部の郊外 地域で土地区画整理事業を誘導あるいは実施してきた。こうして できた市街地の中には, その町名の与え方, 町割の仕方等に独特 の原則が適用されているものがある。特に町割については，旧市 街に見られる伝統的な両側町のシステムを応用したとみられるも のが，昭和の一時期に集中してみられる。

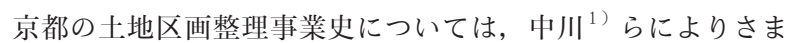
ざまな観点から研究されてきた。またその設計内容や技術的ガイ ドラインについても, 大正期の敷地割調査会によるものを中心に, 鶴田・佐藤 ${ }^{2}$ ， 3)，埒・川上 ${ }^{4)}$ らによる研究蓄積がある。しかし, そうした物的・土木的環境の上に重ねられる社会的なレイヤーで ある「町割」について, どのようなガイドラインが策定され適用 されてきたかについては，ほとんど論じられたことがなかった。

本稿は, 京都市建設局市街地整備課より提供を受けた文書を詳 細に比較し, 路線式町割による両側町構造が採られた昭和初期に 拈ける京都市の土地区画整理事業を中心に, 町割の考え方の変遷 を整理しようとするものである。

\section{2.路線式両側町モデルを持つ土地区画整理地区}

京都市域に扔いては，大正 14 年（1925）に施行された小山花 ノ木地区を皮切りに，100 件以上の土地区画整理事業が施行され てきた。その町割システムはさまざまであるが，昭和 10 (1935） 〜16 年（1941）に換地処分を迎えた地区に集中して両側町モデ ル（路線式町割）の適用が見られる。本論文では, 路線式町割を 用いた両側町モデル（以下，「路線式両側町モデル」という）が 取られた時期の技術的ガイドラインの文書を検討する。それが適 用された地区群としては，賀茂第一区（1926～1935)，紫野門前 町（1926～1935), 賀茂第二区（1928～1936）, 紫竹芝本（1929～ 1936), 西紫野 (1929 1936), 東紫野 (1929 1936), 上堀川 (1932 1937), 下鴨 (1930 1938), 平井高原 (1931 1939), 金

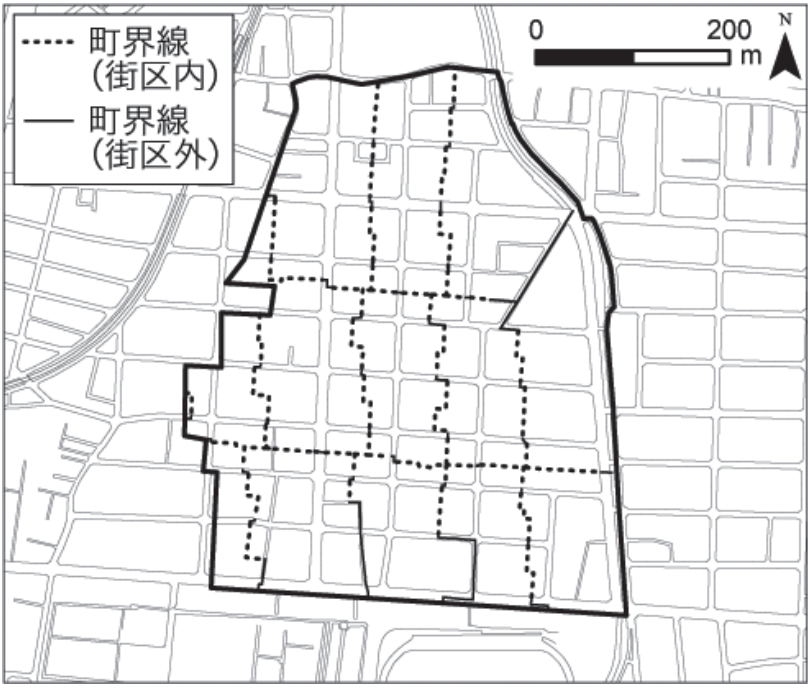

図-1 平井高原地区の町界線

閣寺（1931～1941），西第一（1932～1939）（数字は，事業認可年 度〜換地処分年度) が挙げられる。典型例として, 平井高原地区 （1931～1939）の街区配置と町割を図－1に示す。また，それら が適用された地区群の分布を図ー 2 に示す。

ここまで前置きなしに「路線式両側町モデル」と呼んできたも のについては，文書の詳細比較の中で論じたい。

\section{5 つのガイドラインと 3 つの経緯書}

ここで検討を行なう文書は次のテキスト群である。文書番号を 附し, 本稿巻末に全文を揭出する。文書 $1 \sim 5$ が要綱等のガイド ライン的なもの, 文書 $6 \sim 8$ がそれらの経緯を示すむのである。 なお，これら文書の採録に当っては，適宜旧字体を新字体に改めた。 


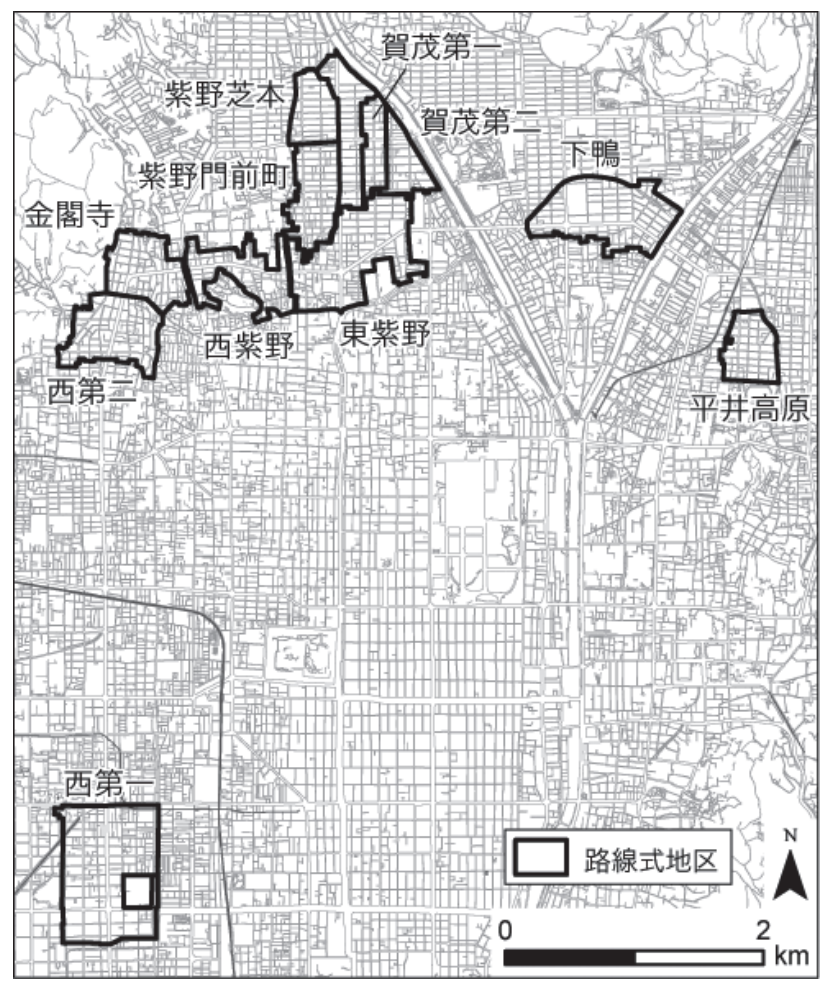

図-2 路線式町割が見られる地区の分布

\section{（1）「整理後の町界町名地番設定（方針の部）」}

「整理後の町界町名地番設定」は, 昭和 6 年 (1931) 11 月発 行の京都市による冊子「大京都の都市計画に就て」の一節をなす ものである。経緯を示す部分と箇条書きされたガイドラインの部 分からなり，ここでは後者を「方針の部」（文書 1) とし，「大京 都」と呼ぶことにする。前者を「経緯の部」(文書 6 ) とし, 分 けて整理する。

（2）「京都市区画整理地区二於ヶル町界町名地番整理方針綱要」

京都市市街地整備課に, 独立した文書として所蔵されていたも のである。今回入手した文書においては, 当時の担当部署や決裁 経過，決定年月日等の記載はない。「京都土地区画整理事業概要」 に示された経緯（文書 7 ）には, 昭和 6 年（1931）に決定された ものとしてその名が出てくる。以下，本稿に扔いては「綱要」と いう（文書 2 )。

\section{（3）「町界町名地番の整理（方針の部）」}

「町界町名地番の整理」は昭和 10 年（1935）の京都府・市に よる「京都土地区画整理事業概要」の一章をなすテキストである。 整理方針が定まるまでの経緯を示す部分と，ガイドラインそのも のの記載とに分かれる。本稿に执いてはガイドラインの部分を「町 界町名地番の整理（方針の部）」とし，あるいは単に「方針」と 略す (文書 3 )。

（4）「(旧）京都市土地区画整理地区内における町名町界地番整 理要綱」

昭和 49 年（1974）に新要綱が施行されるまで効力を持ってい たとされるガイドラインである。施行時期については, 新要綱の 説明文書（文書 8 ）に拈いては, 昭和 6 年 (1931) とされている が, これについては, 後述するように疑問の点がある。今回入手 したものは, 次に挙げる現行の新要綱の文書に添付されていたも のである。以下，本稿に扔いては「旧要綱」という（文書 4 ）。

（5）「京都市土地区画整理地区内における町名町界地番整理要綱 ${ }^{5} 」$ 昭和 49 年 (1974）に施行された新要綱である（文書 5 ）。表紙 において,「49.10.21 市長決定」「都市計画局区画整理課」と明記
されている。

（6）「整理後の町界町名地番設定（経緯の部）」

昭和 6 年（1931）「大京都の都市計画に就て」収録の同名の章 のうち, 経緯をまとめた部分である。本稿においては文書 6 とい う。有識者会議のメンバーについての記載がある。

\section{（７）「町界町名地番の整理（経緯の部）」}

昭和 10 年 (1935) の文書 3 の冒頭に付された経緯文である。 文書 3 と同様, 本稿では収録書籍の章名を取り,「町界町名地番 の整理（経緯の部）」とし，文書 7 という。先に述べたように， この中に「京都市区画整理地区二於ケル町界町名地番整理方針綱 要」の文字がある一方，この「経緯の部」に続く「方針」の位置 づけは明確に示されてはいない。

（8）「京都市土地区画整理地区内における町名町界地番整理要綱 の改正について」

文書 4 同様, 文書 5 に付随する説明文であり, 昭和 49 年 (1974) 改正の意義が，それまでの経緯を含めて書かれているものである (文書 8 )。

\section{4. ガイドライン文書の構成と形式}

以下, 内容の検討に先んじて, ガイドライン 5 文書について, 構成，形式及び内容の比較検討を行なう。

\section{(1) 構成の比較}

文書の構成については，大項目の配列については，「大京都」「綱 要」「方針」「旧要綱」はほぼ共通している。特に「大京都」と「綱 要」「方針」と「旧要綱」はそれぞれ番号の書式等は異なるがほ とんど同じである。「大京都」「綱要」に比較すると「方針」「旧 要綱」では, 詳細項目数の減少が見られる。「新要綱」ではこれ までとはまったく順序が変わるとともに, 街路名と町界町名の標 示に関する項目が消えている。また町の境界や境界線についての 項目が設けられているのも特徵的である。

また「新要綱」では，「町界町名」という大きなくくりが解体 され，全体に階層の浅いフラットな印象のものになっている。

(2) 形式の比較

\begin{tabular}{|c|c|c|c|c|}
\hline 大京都 & 綱要 & 方針 & 旧要綱 & 新要綱 \\
\hline \multicolumn{2}{|c|}{ - } & \multicolumn{2}{|c|}{ - } & $\begin{array}{l}\text { 趣旨 } \\
(1 \text { 項目 })\end{array}$ \\
\hline & \multicolumn{2}{|c|}{ 町界町名 } & $\begin{array}{l}\text { 整理区域 } \\
\text { (1 項目) }\end{array}$ \\
\hline \multicolumn{2}{|c|}{$\begin{array}{l}\text { - 町割の) 万巧 } \\
(1 \text { 項目 })\end{array}$} & \multicolumn{2}{|c|}{ （1 項目） } & $\begin{array}{r}\text { 町の形状 } \\
(1 \text { 項目) }\end{array}$ \\
\hline \multicolumn{2}{|c|}{ •町割 } & \multicolumn{2}{|l|}{ （2 項目） } & $\begin{array}{l}\text { 町の大きさ } \\
(1 \text { 項目 })\end{array}$ \\
\hline \multicolumn{2}{|c|}{ •町面積 } & \multicolumn{2}{|l|}{$\begin{array}{l}{ }^{\circ} \text { "四四䫅 } \\
\text { (1 項目) }\end{array}$} & $\begin{array}{l}\text { 町割りの方式 } \\
\text { (2 項目) }\end{array}$ \\
\hline & (1 項目) & & $\begin{array}{r}\text { 町の境界 } \\
(1 \text { 項目 })\end{array}$ \\
\hline \multirow{2}{*}{\multicolumn{2}{|c|}{$\begin{array}{l}\text { (4 項目及理由) } \\
\text { ·街路名 } \\
\text { (1 項目及理由) }\end{array}$}} & \multirow{2}{*}{\multicolumn{2}{|c|}{$\begin{array}{l}\text { - 町名 } \\
\text { (1 項目) } \\
\text { · 街路名 } \\
\text { (1 項目) }\end{array}$}} & $\begin{array}{c}\text { 町の境界線 } \\
\text { (1 項目) }\end{array}$ \\
\hline & & & & $\begin{array}{l}\text { 町の名称 } \\
\text { (4 項目) }\end{array}$ \\
\hline \multicolumn{2}{|c|}{$\begin{array}{l}\text { 地番 } \\
\text { (5 項目及理由) }\end{array}$} & \multicolumn{2}{|l|}{$\begin{array}{l}\text { 地番 } \\
(5 \text { 項目) }\end{array}$} & $\begin{array}{l}\text { 地番 } \\
(4 \text { 項目 })\end{array}$ \\
\hline \multicolumn{2}{|c|}{$\begin{array}{r}\text { 町界町名の標示 } \\
(1 \text { 項目及理由) }\end{array}$} & \multicolumn{2}{|c|}{$\begin{array}{l}\text { 町界町名の標示 } \\
\text { (1 項目) }\end{array}$} & - \\
\hline \multicolumn{2}{|c|}{$\begin{array}{l}\text { 学区界·組合等について } \\
\text { の記述 }\end{array}$} & \multicolumn{2}{|c|}{-} & $\begin{array}{l}\text { 附則 } \\
\quad(2 \text { 項目) }\end{array}$ \\
\hline
\end{tabular}


各ガイドラインの内容の検討に入る前に，それぞれの形式を見 ておくことにする。「大京都」「綱要」「方針」は，文語体で書かれ， 送り仮名は歴史的仮名遣いである。特に「綱要」「方針」は片仮 名書きで句読点の打ち方なども現代の文とはだいぶ違っており, 決して読みやすいものとはいえない。一方「旧要綱」は「方針」 とほぼ同内容ながら，ほぼ口語体，漢字平仮名まじり文で書かれ 平易な印象を与えるものとなっている。

「大京都」及び「綱要」には随所に「註」が加えられている他， 各大項目に詳細な「理由」が附されている。初期のガイドライン がどのような考えのもとに生まれたのか考える上で，参考になる ものである。「方針」に扔いては「理由」欄はなく，ところどこ ろに「註」が設けられているのみである。「旧要綱」は「方針」 とほとんど同内容ながら，「註」は設けられていない。

\section{5. ガイドライン文書の内容の比較検討}

ガイドライン文書の主な項目について相互比較を試みる。まず, よく似た構成を持つ「大京都」「綱要」「方針」「旧要綱」の共通 点と差異について検討を行い, 次いでそれらと「新要綱」との比 較を行なうこととする。

(1) 戦前のガイドライン群の検討

(i )「大京都」と「綱要」について

この 2 文書はほとんど同一の内容を持つ。「綱要」において「街 廓」とされているところが「ブロック」と書かれていること, 街 路名称に付す字として「北」「南」等の他に「上」「下」等が挙げ られていること, その他句読点の位置や表記の差など, 細かな差 異が見られる。

「大京都」は昭和 6 年（1931）11月に発行された冊子に収録 されたものであり,「綱要」も昭和 6 年 (1931) 3 月に決定され たとの記事が文書 7 に見られ, 時期的にごく近いものと考えられ る。上で見たように，構成もほぼ同じである。

(ii)「方針」と「旧要綱」について

この 2 文書も, 内容的にはほとんど同一である。「方針」は昭 和 10 年（1935）の冊子に記載されているもので, その時点では 最新のものであったと考えられる。一方「旧要綱」は文書 8 によ れば昭和 6 年 3 月のものとされるが，同年のものと思われる「大 京都」「綱要」とは異なった内容を持つ。口語, 新仮名遣いといっ た点からは，むしろより新しい時代に書かれたもののように見え る。

\section{（iii）「綱要」「方針」の比較検討}

これら 4 つのガイドライン文書は, 上で見たように構成及び内 容の類似性から大きく 2 つのグループに分けられる。ここでは「綱

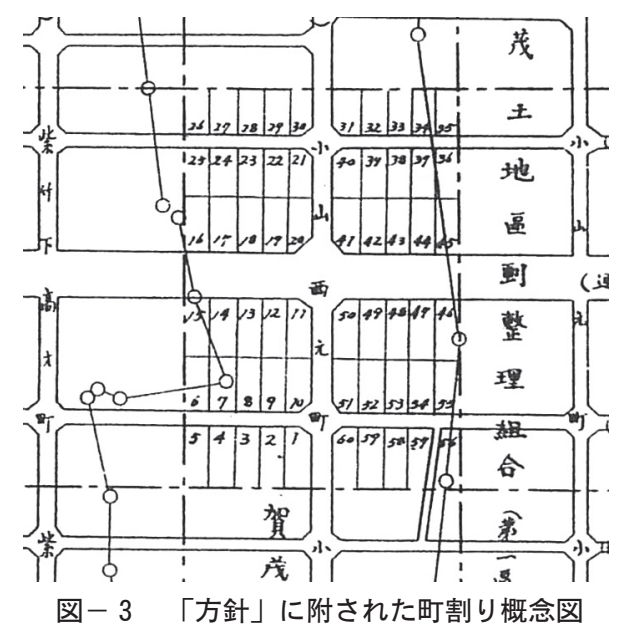

要」及び「方針」にそれぞれを代表させ，比較を試みたい。 (1)町割の方式について

町割の方式については，2文書とも「路線式を原則とする」と の内容の，ほぼ同一の文言である。特に「綱要」においては，「路 線式」「街廓式（新旧要綱においては「街かく式」）」「結合式」の 3 方式についての「註」が付記されている。それによれば，「路 線式」とは「街路に沿う建築敷地をもって町を構成するもの」,「街 廓式」とは「 1 または 2 以上の街廓をもって町を構成するもの」, 「結合式」とは「路線式を加味した街廓式で主要道路の両側に並 列する街廓集団をもって町を構成するもの」とされる。これら 2 文書に扔いて原則とされている「路線式」では, 町が道路で仕切 られるのではなく, 町の中に道路がある構造であることがわかる。

「綱要」に扔いては, 次の「町割」の項にて「路線式」を採用 する理由が 5 項目列挙されている。その中で「路線式八通信訪問 ヨ便利ニシ修交関係公同自治関係等二於テモ他ノ方式ヨリハ比較 的効果多シ」「旧市ノ町割八路線式 ヨ尊ヒ旧市卜ノ町割ノ連絡 7 取ルタメ」の 2 項目は特に注目され る。前者は道路を介したコミュニティ形成について言及している からであり, 後者は京都の都市的伝統としての路線式 (両側町モ デル）に言及しているからである。京都の旧市街地の町割が両側 町となっていることはよく知られているが，その伝統を新市街地 に援用しようという考えがうかがえる。

(2)町の形状

「町割」については，「方針」においては，「南北に長い短冊形」 とし, 例外として「四條七條（京都市においては東西方向の幹線）」 の如き大通りにおいては商店街を形成する関係上東西に長い短冊 形でもよいとしている。それに対し「綱要」では, 同様の例外を 挙げるとともに，市の「南部及び北部」においては「南北に長い 短冊形」「東部及び西部」に扔いては「東西に長い短冊形」とし ているところが異なる。

(3)町面積

2 文書の記述は住宅地については「5,400 坪 $\left(17,700 \mathrm{~m}^{2}\right) 」$ 程 度ということで共通している。「綱要」に扔いては工業地につい て「7,000 10,000 坪 $\left(23,140 \sim 33,060 \mathrm{~m}^{2}\right) 」$ が挙げられている。 「綱要」の「理由」においては, $2,000 \sim 3,000$ 坪 $\left(6,610 \sim 10,000 \mathrm{~m}^{2}\right)$ という旧市街の町がコミュニティの細胞的単位としては過小であ るという認識が示され，住宅地においては一筆あたり 50〜100 坪, 工業地においては一筆あたり 70 150 坪の敷地が 100 筆程度集合 するモデルを提示している。

(4)町区域

町区域についてもこれまでの項目と同じように，「綱要」にお いては「南部及ビ北部」と「東部及ビ西部」でやや異なったモデ ルが示され，「方針」ではそれらが取捨選択され，単純化されて いる。「南部及ビ北部」のモデルのみが，「方針」に残っている。

「綱要」に打ける「東部及ビ西部」のモデルは, 先の「東部及 ビ西部二於テハ〜東西二長キ短冊形卜ス」とあるのに呼応するも ので,「南部及ビ北部」のモデルを 90 度回転させたものとみるこ とができる。「町割」の項と併せ読むと，「綱要」においては相互 に連担する土地区画整理事業群によって整備される環状の幹線道 路に対し, 長辺が直行する形で短冊形の町割が構想されていたよ うである。「西第一地区」（1932～1939）は実際に西部地区で路線 式両側町モデルが適用された事業であるが，ここでも南北に長い 短冊形町割が使われており,「綱要」にみるような西部東部にお ける東西に長い町は実際には造成されなかった。

この「町区域」の項においては，これまで「町割の方式」「町割」 「町面積」等でばらばらに挙げられてきた要素が初めて構造化さ れる。約 100 筆の敷地群が, 道路を軸に南北に長い短冊形に構造 化されるのである。「方針」において「綱要」より簡明なものとなっ 
た当該部分を引く。「原則トシテハ一箇町内二南北ノ道路一條卜 東西ノ道路三條习含マシムルモノトシ, 先ズ街廓ノ中央 7 南北二 縦貫スル線ニヨリ各街廓习半裁シ斯クシテ生ジタル南北ニ通ヅル 道路ノ両側二二箇ヅ〉相対スル半街廓南北両端二一箇ヅ〉相対ス ル四分ノ一街廓卜ノ一団（結局半街廓四箇四分ノ一街廓四箇合計 三街廓ヨリナル） ヨ以テ町ノ基本区域卜ス」。これを図解すると 図ー 3 のようになる。これは昭和 10 年代に換地処分を迎えた事 業の多くに見られる実際の町割構造ときわめてよく似ている。こ れが，本稿でもこれまで言及してきた路線式両側町モデルである。 (5)町名について

これまでのところは，「綱要」と「方針」の内容は若干の相違 を含みつつも, 基本的な考え方は共通するところが多かった。し かしこの「町名」に扔いては，抜本的に異なる記述となっている。

「綱要」における町名原則は, 町の内部で交叉する 2 本の街路 名を重ねて町名とするというシステマティックなものである。交 叉する道路の名を重旼交差点を名付けるというのは, 京都の旧 市街地の住所表示の方法に近い ${ }^{6)}$ 。「理由」に扔いて, 旧市街地 では「○○通 $\triangle \triangle$ 通上ル」のような通り名之町名とを重ねがて長 なものとなっていることを批判し, 町名と街路名（中心交差点名） を一致させることで，より簡明な住所表示をなすことを目指した ことが書かれている。この街路名と町名を一致させる考えは,「綱 要」を貫くものの一つでもあり，先に見た「町割」の項の「理由」 や，「街路名」の項の内容にもそれは表れている。

「方針」での考え方は，それぞれの場所の旧大字名之旧小字名 を組み合わせて, 新町名とするというものである。実際に施行さ れた地区においては, この方法で町名が付けられている。この「方 針」「旧要綱」の方法は, それぞれの場所の歴史性を尊重するも のといえる。

(6)街路名について

町名との関わりによって, 街路名の取扱にも大きな違いが見ら れる。「綱要」では街路名は数多くの町の名に関わってくるため, 多くの道街路に「公称名」を付ける必要が生じる。「綱要」にお ける「其他ノ通リ八何 (北) 通何 (南) 通, 又八何西通何東通（例 ヘバ紫野北通又八紫野南通）卜呼バシムルモコノ通名八通称二止 メ公称トシテ用ヒザルモノトス」という記述は興味深い。主要街 路名に東西南北を付してサブ街路名とするのは，通称名としては 良いが公称名とすべきでないといっている。ここには, 町名う街 路名は, やはりなんらかの固有的な名称を持つべきであるという 考えをうかがうことができよう。

「方針」に扔いては，異なる町名方式が提示されているため, 町名之街路名を関連づけた「綱要」に比べると, ごくあっさりと した記述になっている。旧市街地から連絡する既に名のある街路 を除いては, 主要街路だけ名付け, あとは東西南北を付して済ま すということである。

(7)総合的比較

以上「町界町名」の部分について, 初期ガイドライン文書の項 目毎の比較を行なったが，ここでその全体を振り返ることとする。 新都市のミクロな細胞となる町割や, 町と街路の関係について は,「綱要」「方針」に代表される 2 つ文献群の基本的考え方は 共通している。それは本稿に打いて路線式両側町モデルと呼んで きたものである。これを共有しながらも,「綱要」で提示されて いた東部及び西部での, 「東西に長い短冊形」や, その構造につ いての記述は，「方針」では見られなくなる。

「綱要」においては東部及び西部では横長の町が構想されてい たことからは, 都市のマクロな構造として環状幹線道路に直行す る形で放射状に町が配されるイメージがあったと思われるが，「方 針」では，このような都市全体を貫く構造への言及は見られない。 一方, 町名之街路名についての考え方については,「綱要」で
提示された街路名を町名と一致させるシステマティックな方法は 「方針」では破棄され，現地の旧字名等を活かす方法が採られる。 以上，さまざまな相違点を持つ初期ガイドライン文書群である が，町割においても町名に扔いても，一定の歴史主義的な性格を 持っていることには注目したい。

こうした性格については，昭和 6 年（1931）の文書 6 において 「各地区の沿革を稭へその固有の伝統を保持しつ〉」「昨年（著者 註：昭和五年）十一月斯界の権威たる京大教授西田直二郎，石橋 五郎両博士，郷土史家猪熊淺麿，出雲路通次郎氏等を該委員に嘱 託し調査審議を重ねる事… 昭和 10 年（1935）の文書 7 におい て「昭和五年十一月二十六日京都帝大教授其ノ他故事二通暁セル 識者二嘱託シ…」とあることとも整合的である。西田は国史学者, 石橋は地理学者である。ガイドライン策定に当っての, 京都固有 の伝統への配慮は企図されてのものであったことがわかる。なお， 上記両文書に見える昭和 5 年 11 月の有識者会議は同一の屯のと みられ, 翌 6 年の「綱要」に繋がっていくものである。

\section{(4)「新要綱」の検討}

これまで論じてきた 4 文書は，昭和 6 年（1931）から昭和 10 年（1935）の間に成立したものと考えられ，その時期は比較的近 接している。しかし新要綱の施行は昭和 49 年（1974）となって おり，その間にはほぼ 40 年の開きがある。時間が開いているだ けでなく，その間には第二次世界大戦と高度成長という大きな社 会的な動きがあった。「方針」「旧要綱」ができた頃とは「時代が 違う」のであり，その内容も大きく変わっている。

まず最大の変更点は，それまでの原則であった「路線式」が撤 回され「街かく式（街廓式）」が原則となった点である。面積規 模については, 住宅地（他に商業地, 工業地の設定あり）であれ ば $150 \mathrm{~m}^{2} /$ 筆 $\times 200$ 筆 $=30,000 \mathrm{~m}^{2}$ を標準とする旨の記載がある。 旧要綱に比して, 筆数之町面積の拡大が見られる。筆数は 2 倍, 町面積は 1.7 倍となっている。この 200 筆を「方針」に見える三 街廓相当の町区域の路線式両側町モデルに組み込むのは, 幾何学 的に困難であると思われる ${ }^{7)}$ 。そしてかつて「南北に長い短冊形」 とされた町の形状は，ここでは「お拉むね四角形の一団」とされた。 興味深いのは, 町の境界についての記述が多く見られることで

表 -2 一箇町の面積, 筆数 (住宅市街地)

\begin{tabular}{|l|c|c|c|}
\hline \multicolumn{1}{|c|}{ 市街地種類 } & 面積 $\left(\mathrm{m}^{2}\right)$ & 筆数 & 備考 \\
\hline 旧市街地 & $6,610 \sim 10,000$ & - & 「綱要」参照 \\
\hline 「方針」「旧要綱」 & 17,700 & 100 & \\
\hline 「新要綱」 & 30,000 & 200 & \\
\hline
\end{tabular}

\section{表 -3 新要綱における町界の取り扱い}

\begin{tabular}{|c|c|c|}
\hline $\begin{array}{l}\text { 「新要綱」 } \\
\text { の項目名 }\end{array}$ & $\begin{array}{c}\text { 「新要綱」における町界に } \\
\text { 関する主な記載内容 }\end{array}$ & $\begin{array}{c}\text { 「方針」「旧要綱」の } \\
\text { 記載とその実際 } \\
\end{array}$ \\
\hline 町の形状 & 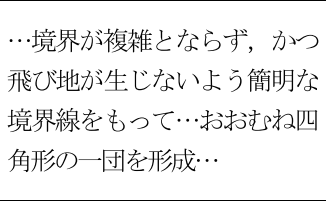 & $\begin{array}{l}\text { 街区内の換地筆界線が町 } \\
\text { 界となるため, 微細なク } \\
\text { ランクが多数生じ, 町は } \\
\text { 概敢短冊状ながら複雑な } \\
\text { 状状 (図- } 1 \text { 参照) }\end{array}$ \\
\hline 町の境界 & $\begin{array}{l}\text { ‥道路, 河川, 水路, 鉄道等 } \\
\text { 恒久的な施設をもって定める } \\
\text { ‥現地の状況によりこれによ } \\
\text { り難い場合においては, 筆界 } \\
\text { 線等をもって定めることがで } \\
\text { きる.. }\end{array}$ & $\begin{array}{l}\text { 街区内の換地筆界線（民 } \\
\text { 民境界）が主な町界線と } \\
\text { なる. これらは公共的に } \\
\text { は保全され難い. 道路や } \\
\text { 河川等の公共施設を境界 } \\
\text { とするの例外的 }\end{array}$ \\
\hline 町の境界線 & $\begin{array}{l}\text { 町の境界線は, 公共施設等の } \\
\text { 側線をもつて定める... }\end{array}$ & $\begin{array}{l}\text { 道路河川を境界とする時 } \\
\text { は中心線をもってとの記 } \\
\text { 載あり }\end{array}$ \\
\hline
\end{tabular}


ある。条文としても「町の境界」「町の境界線」という項目が独 立して設けられているほか,「町の形状」においても, 町の境界 に関する記述が見られる。このことは,「方針」「旧要綱」ではあ まり強く意識されていない町界線について, あえて定めなければ ならない現実的な問題が生じていたことがうかがわれる。これら， 「新要綱」に見られる町界についての記述と，「方針」「旧要綱」 による地区の実際を整理すると，表一 3 のようになる。

昭和初期につくられた「方針」「旧要綱」に準拠した地区では, 街区内を縫うように走る町界線は微細な屈曲を多数持つ形状とな り，また公衆の目につかず公的には保全しにくい街区の奥の民間 敷地同士の境界を走ることとなる。「新要綱」の「町の境界線」 の項では, 公共施設によって境界を定める際に, 道路・河川中心 線ではなく, 官民境界が確実に現地に表示される側線が選ばれて いる。ここでも町界を, 誰からも確認できる状態にすることと, 恒久的に公共において管理できる場所に設けることが, 強く意識 されているといえる。

\section{6. ガイドラインの制定経緯について}

(1)「大京都」「綱要」「方針」「旧要綱」について

昭和初期の「大京都」「綱要」「方針」「旧要綱」は，どのよう な順番で作られ，お互いによ゙のような関係をもつのだろうか。

表 -4 は, 昭和 6 年 (1931)「大京都の都市計画に就て」及び 昭和 10 年 (1935)「京都土地区画整理事業概要」の経緯の部の記 載事項を比較したものである。昭和 6 年（1931） 3 月時点で「京 都市区画整理地区内二於ケル町界町名地番整理方針綱要」の名之, 「東は賀茂街道, 西は大徳寺通, 北は旧市郡境, 南は疏水を境亡 する五十余万坪の区域」「賀茂第一, 第二, 上堀川, 紫竹芝本, 紫野門前, 東紫野」といった具体的な対象地区名が出てくる。先 に見たように「綱要」は北部地区のみならず, 東部西部地区も含 めたマクロな都市構造への言及があるものであった。その後上記 地区の組合関係者を入れた連合委員会, 連合協議会が開催される 中で，町界町名の具体案の検討と同時に修正されていき，「方針」 にみるようなものになっていったものと思われる。

この過程で起きたことはまず第一に，京都市全体のマクロな構 造への言及の欠落と「綱要」で北部南部地域に限るとされた「南 北に長い短冊形」のクローズアップ, 第二に街路名町名の考え方 の変更である。この第一の変化は, 経緯を鑑みると「方針」が上 記地域を対象とした「具体案」であって, 市全体における原則を 示したガイドラインではなかった可能性を示している。「方針」 が「京都土地区画整理事業概要」の時点で要綱としての位置付け を持っていないこともその可能性を支持するものであろう。

「綱要」については，文書 7 において昭和 6 年 (1931) 3 月に 決定されたとの記載が見える。また「旧要綱（旧京都市土地区画 整理地区内における町名地番整理要綱)」については, 文書 8 に やはり昭和 6 年 (1931) 3 月に決定されたと書かれている。しか しながら, 先に検討したように「綱要」と「旧要綱」(「方針」と ほぼ同内容）とは, 路線式両側町モデルを共有しながらむ, 町名 設定の考え方等随所に大きな違いが見られ, 同じ昭和 6 年 3 月に 決定されたということは疑わしい。しかし「新要綱」の起案時に おいては,「綱要」と「旧要綱」が同一視されているかのように 見受けられるのである。

「方針」（旧要綱とほぼ同内容）はガイドラインとしての表題 を持たないが，文書 7 の経緯を受けての成果として書かれている ことから, 昭和 6 年 (1931）12月 22 日の「協議会」, あるいは 昭和 7 年（1932）10月の「連合委員会」にて決されたものと考 えられ，収録されている「京都土地区画整理事業概要」が発行さ れた昭和 10 年 (1935) では最新のものであったと考えられる。「方 針」と「旧要綱」はほとんど同内容ながら, 前者は文語・旧仮名
遣い・漢字片仮名まじり文, 後者は口語・新仮名遣い・漢字平仮 名まじり文という相違がある。ここから，現在「旧要綱」とされ ているテキスト自体は，戦後の国語改革以降にリライトされたも のであろうということ，またその際に「方針」が参照されたであ ろうということを推测することには，一定の合理性があると考え られる。その際に「綱要」との同一視が起きた可能性もあるが, ここではその可能性を指摘するに留める。

ただ「方針」が，ある時点で要綱のように扱われ，北部地域以 外に援用されるようになったことは間違いない。「綱要」に立ち 戻れば，西部地域での事業において「東西に長い短冊形」の町割 を軸とした具体案が作られてもよかったはずであるが，西第一地 区（1932-1939）で明瞭な「南北に長い短冊形」が見出されるこ とは，「方針」の全市的ガイドライン化，事実上の要綱としての 運用が行われたことを示すものである。

\section{(2) 新要綱の周辺}

文書 8 は,「新要綱」の制定理由として,「時代の推移に伴い, 実情に沿わない面がでてきており，現在ほとんど啇用されなくなっ ている」ことを挙げている。

この箇所からは,「新要綱」が施行されるまで「旧要綱」が墨 守されていたわけではなく，それよりも早い時期に既に使われな くなっていたことがうかがわれる。表一 5 は, 京都市で昭和 51 年（1976）までに施行された土地区画整理事業の一覧である。順 序は換地処分時期によって整理した。

○を付したのは住宅地図等から「旧要綱」等に見られる路線式 両側町モデルの町割が明瞭に見て取れる地区である。本稿冒頭で 屯触れたように, 路線式両側町モデルは昭和 10 (1935) 〜 16 年 （1941）に集中して見られ，その後は一地区も施行されていない。

このタイプが見られるようになる昭和 10 年（1935）は，いう

表 -4 「大京都の都市計画に就て」及び 「京都土地区画整理事業概要」にみる経緯

\begin{tabular}{|c|c|c|c|}
\hline \multicolumn{2}{|c|}{$\begin{array}{c}\text { 大京都の都市計画に就て } \\
\text { (昭和6 年) の記載 }\end{array}$} & \multicolumn{2}{|c|}{$\begin{array}{c}\text { 京都土地区画整理事業概要 } \\
\text { (昭和 } 10 \text { 年) の記載 }\end{array}$} \\
\hline 時期 & 出来事 & 時期 & 出来事 \\
\hline $\begin{array}{l}\text { S5. } 11.26 \\
(1930)\end{array}$ & $\begin{array}{l}\text { 町界町名地番設定調查委 } \\
\text { 員会 (第1回) }\end{array}$ & $\begin{array}{l}\text { S5. } 11.26 \\
(1930)\end{array}$ & $\begin{array}{l}\text { 町界町名地番二関スル協議 } \\
\text { 会 (第1 回) }\end{array}$ \\
\hline $\begin{array}{l}\text { S6. } 3 \\
(1931)\end{array}$ & $\begin{array}{l}\text { 「調査審議を重㸚る事十 } \\
\text { 数回, 其第一次調查とし } \\
\text { ては東は賀茂街道, 西は } \\
\text { 大徳寺通, 北は旧市郡境, } \\
\text { 南は疏水を境とするる五十 } \\
\text { 余万坪の区域に対し此程 } \\
\text { 成案を見るに至つた」 }\end{array}$ & $\begin{array}{l}\text { S6. } 3 \\
(1931)\end{array}$ & $\begin{array}{l}\text { 町界町名地番二関スル協議 } \\
\text { 会 (第8回) } \\
\text { 「京都市区画整理地区内二 } \\
\text { 於ケル町界町名地番整理方 } \\
\text { 金十綱要」「賀茂第一, 第二上 } \\
\text { 堀川, 紫竹芝本, 紫野門前, } \\
\text { 東紫野組合地区二於ケル設 } \\
\text { 定案」 }\end{array}$ \\
\hline 11 & $\begin{array}{l}\text { 「大京都の都市計画に就 } \\
\text { て」発行.「綱要」とほぼ } \\
\text { 同内容のテキストが収録 } \\
\text { される }\end{array}$ & 12. 22 & $\begin{array}{l}\text { 町界町名地番二関スル協摰 } \\
\text { 会 (第9回) } \\
\text { 上記を修正 }\end{array}$ \\
\hline & $\begin{array}{l}\text { 近い将来のこととして記 } \\
\text { 述: 「関係諸組合中よりも } \\
\text { 委員を選任し, 聯合協議 } \\
\text { 会を開いて具体案决定の } \\
\text { 後, 不日市へ稟議する事 } \\
\text { となつている」 }\end{array}$ & $\begin{array}{l}\text { S7. } 10 \\
(1932)\end{array}$ & $\begin{array}{l}\text { 「北部区画整理区域町界町 } \\
\text { 名地番設定調査連合委員 } \\
\text { 会」 } \\
\text { 前協議会の終正案をさらに } \\
\text { 蓚正 }\end{array}$ \\
\hline & $\begin{array}{l}\text { 近い将来のこととして記 } \\
\text { 述:「今後工事完成の地区 } \\
\text { 毎に逐次新町名が市民諸 } \\
\text { 君に相見えるであらう」 }\end{array}$ & $\begin{array}{l}\text { S10.1.15 } \\
(1935)\end{array}$ & $\begin{array}{l}\text { 市会「賀茂第一, 第二上堀 } \\
\text { 川, 紫竹芝本, 紫野門前, } \\
\text { 東紫野, 西紫野」 各組合の } \\
\text { 町界町名を決定 }\end{array}$ \\
\hline
\end{tabular}


表 - 5 路線式両側町モデルの採用時期

\begin{tabular}{|c|c|c|c|c|}
\hline 地区名 & 認可年月日 & $\begin{array}{c}\text { 換地処分 } \\
\text { 年月日 }\end{array}$ & $\begin{array}{l}\text { 路線式両側町 } \\
\text { モデルの有無 }\end{array}$ & 備考 \\
\hline 小山花ノ木 & 1925.10 .15 & 1925.12 .16 & $\times$ & \multirow{4}{*}{$\begin{array}{c}1931 \text { 「綱要」 } \\
\text { 「大京都」 }\end{array}$} \\
\hline 高徳寺 & 1927.9 .16 & 1930.4 .14 & $\times$ & \\
\hline 洛北 & 1927.11.12 & 1931.3.31 & $\times$ & \\
\hline 吉田近衛 & 1930.7 .15 & 1931.4 .15 & $\times$ & \\
\hline 賀茂第一区 & 1926.7 .26 & 1935.7 .1 & 0 & \multirow{41}{*}{$\begin{array}{c}1935 \text { 「方針」 } \\
\text { 「旧要綱」 }\end{array}$} \\
\hline 紫野門前町 & 1926.3 .4 & 1935.10 .1 & 0 & \\
\hline 賀茂第二区 & 1928.12 .13 & 1936.1 .10 & $\bigcirc$ & \\
\hline 紫竹芝本 & 1929.3.29 & 1936.2.1 & 0 & \\
\hline 西紫野 & 1929.1 .10 & 1936. 3.20 & O & \\
\hline 東紫野 & 1929.11 .22 & 1936.10 .20 & 0 & \\
\hline 上堀川 & 1932.4 .4 & 1937.2 .20 & 0 & \\
\hline 下鴨 & 1930.12 .27 & 1938.10 .1 & 0 & \\
\hline 西第一 & 1932.4 .4 & 1939.2 .1 & 0 & \\
\hline 平井高原 & 1931.8 .18 & 1939.2.10 & 0 & \\
\hline 北第一 & 1933.10 .27 & 1939.9 .26 & $x$ & \\
\hline 南第一 & 1932.11 .21 & 1940.3 .15 & $\times$ & \\
\hline 加茂之荘 & 1934.3 .28 & 1940.3 .15 & $\triangle ※$ & \\
\hline 金閣寺 & 1931.9.23 & 1941.7 .14 & 0 & \\
\hline 松賀茂 & 1936.5 .7 & 1941.7 .25 & $\triangle ※$ & \\
\hline 西第二 & 1934.3.10 & 1941. 8.20 & 0 & \\
\hline 東第一 & 1935.3 .7 & 1943.4 .15 & $\times$ & \\
\hline 南第四 & 1937.5 .24 & 1943.7 .1 & $\times$ & \\
\hline 北第二 & 1938.5 .14 & 1943.9.20 & $\times$ & \\
\hline 東向 & 1940.2 .1 & 1943.9 .20 & $\times$ & \\
\hline 桃山 & 1932.5.19 & 1943.10 .18 & $\times$ & \\
\hline 西寺 & 1931.6 .1 & 1944.3.23 & $\times$ & \\
\hline 桂駅西口 & 1934.7 .13 & 1948.11 .1 & $\times$ & \\
\hline 北白川 & 1929.6 .8 & 1948.12 .1 & $\triangle ※$ & \\
\hline 修学院一人 & 1947.5 .1 & 1950.3 .23 & $\times$ & \\
\hline 西ノ京北部 & 1928.5 .16 & 1950.10 .1 & $\times$ & \\
\hline 一乗寺一人 & 1947.5 .1 & 1950.10 .1 & $x$ & \\
\hline 南第三 & 1936.5.21 & 1951.2. 12 & $\times$ & \\
\hline 上桂 & 1934.4 .20 & 1954.3 .15 & $\times$ & \\
\hline 西院北部 & 1928.7 .23 & 1954.7 .1 & $\times$ & \\
\hline 洛南 & 1940.4 .17 & 1956.4 .20 & $x$ & \\
\hline 南第二 & 1935.6 .26 & 1956.10 .26 & $\times$ & \\
\hline 松平筑前 & 1931.2 .2 & 1956. 11.13 & $\times$ & \\
\hline 東第四 & 1937. 12.20 & 1958.6 .27 & $\times$ & \\
\hline 東第三 & 1938.2 .10 & 1959.1.13 & $\times$ & \\
\hline 西七条 & 1931.2 .3 & 1960.3 .29 & $\times$ & \\
\hline 西第三 & 1935.6 .26 & 1960.3 .29 & $\times$ & \\
\hline 東第二 & 1936.10 .27 & 1960.3 .29 & $\times$ & \\
\hline 西第五 & 1938.6 .21 & 1960.3.29 & $\times$ & \\
\hline 吉祥院西 & 1939.11 .27 & 1960.3 .29 & $\times$ & \\
\hline 今宮 & 1939.6 .14 & 1960.3 .29 & $\times$ & \\
\hline 久世工業扵地 & 1963.12 .9 & 1965.9 .2 & $x$ & \multirow{20}{*}{$\begin{array}{l}\text { 1962「住居 } \\
\text { 表示に関す } \\
\text { る法律」 } \\
\text { (京都市で } \\
\text { は参考とす } \\
\text { るも採用せ } \\
\text { ず) }\end{array}$} \\
\hline 吉祥院東 & 1941.2. 18 & 1965.10 .14 & $\times$ & \\
\hline 安寧 & 1957.7 .29 & 1966.2 .17 & $x$ & \\
\hline 䣨是醐団地 & 1965.3 .29 & 1966. 8.11 & $\times$ & \\
\hline 吉祥院北 & 1941.11 .25 & 1966.9 .29 & $x$ & \\
\hline 島津一人北 & 1957.12 .3 & 1966.9.29 & $x$ & \\
\hline 一乗寺 & 1957.3 .8 & 1967.6 .1 & $\times$ & \\
\hline 西第四 & 1935.10 .7 & 1967.10.19 & $\times$ & \\
\hline 中久世 & 1961. 11.8 & 1968.4 .25 & $\times$ & \\
\hline 大宮 & 1960.3 .31 & 1968.5 .16 & $\times$ & \\
\hline 阪急上里団地 & 1966.5 .20 & 1968.5 .30 & $\times$ & \\
\hline 清水焼団地 & 1964.11 .30 & 1969.11 .13 & $\times$ & \\
\hline 吉祥院石原 & 1966.3. 18 & 1969.11 .13 & $\times$ & \\
\hline 葛野 (四条工区) & 1957.11 .15 & 1969.11 .27 & $\times$ & \\
\hline 西浦 & 1962.3 .30 & 1970.3 .5 & $x$ & \\
\hline 島津一人 & 1939.3 .7 & 1970.7 .2 & $\times$ & \\
\hline 葛野 (五条工区) & 1957.11 .15 & 1971.5 .27 & $\times$ & \\
\hline 上賀茂 & 1963.8 .2 & 1972.6 .22 & $\times$ & \\
\hline 醍配胡南団地 & 1970.7 .6 & 1972.8 .10 & $\times$ & \\
\hline 上鳥羽 & 1960.6.16 & 1972. 8.17 & $\times$ & \\
\hline 岩倉団地 & 1971.7 .8 & 1975.6 .26 & $x$ & \multirow{2}{*}{$\begin{array}{l}\text { 1974「新要 } \\
\text { 綱」 }\end{array}$} \\
\hline 深草万帖敷 & 1969.7.24 & 1976.7 .8 & $\times$ & \\
\hline
\end{tabular}

ら逸脱するもの. その形態の分析と導入経緯については別途検討を要寸る。
までもなく昭和 5 年以来の議論を受け，市会にて「賀茂第一，第 二上堀川, 紫竹芝本, 紫野門前, 東紫野, 西紫野」各組合の町界 町名が決定され，「方針」が掲載されている「京都土地区画整理 事業概要」が発行された年である。路線式両側町モデルは，この 後 10 年間も保たなかったことがわかる。表一 5 からは, 文書 8 に見られるとおり，相当早い時期から「方針」「旧要綱」の町割 モデルが使われなくなってきたことが明瞭に読み取れるのである。 路線式両側町モデルが使われなくなっていった背景には, 既存建 物群が多数ある場合の困難さ ${ }^{8)}$, 集合住宅や工場などが要求する スーパーブロック型の画地 ${ }^{9)}$ など, 宅地のあり方の多様化など が想像されるが，実際にどのような過程があったのかは未解明で ある。また，「新要綱」において町界の表示と保全が強く意識さ れているが，それが要綱の改訂にどのように関わっているのかも， 今後明らかにすべき課題である。

なお，文書 8 には，「『住居表示に関する法律』等を参考にして いるのが現状である」との記述があるが，「方針」「旧要綱」の町 割モデルが使われなくなってから，昭和 37 年（1962）の同法施 行前後とで, 町割の考え方によ゙のような変化が見られるのかも興 味のあるところである。

\section{7.まとめ}

以上，京都市における土地区画整理事業に援用されてきた，町 割についてのガイドライン文書群について比較検討を行い，その 変遷について論じた。

昭和 10（1935）～16 年（1941）に換地処分を迎えた地区群に 特徵的に見られる「路線式両側町モデル」の町割は,「大京都の 都市計画に就て (大京都)」「京都市区画整理地区二於ヶル町界町 名地番整理方針綱要（綱要）」「京都市土地区画整理事業概要」に 掲載された「町界町名地番の整理」の「方針」，昭和 49 年 (1974) に廃された「旧京都市土地区画整理地区内に打ける町名町界地番 整理要綱（旧要綱）」に明確に記載されていた。そして昭和 6 年 に決定されたという「綱要」においては，その路線式両側町モデ ルのコミュニティ形成への寄与の可能性や, 京都の都市構造の伝 統との関わりが明瞭に意識されていた。

これら戦前のガイドライン文書は, いずれも「路線式両側町モ デル」を持つが,「綱要」において東部と西部に構想された東西 に長い短冊形の町や，街路名之一致させた町名システム等は，昭 和 6 （1931）～７（1932）年に成立したと考えられる「方針」「旧 要綱」においては採用されていないなど，内容には変遷が認めら れる。

経緯から見ると，「方針」が当初においては北部地域を対象に「綱 要」からブレイクダウンされた具体案であった可能性がある。こ れがそのまま要綱として西部地区にも使われるようになり, 当初 「綱要」にあった「東西に長い短冊形」の路線式両側町モデルの 地区は実現しなかったものと考えられる。

「綱要」に見られる，街路の交差点名と一致させた町名システ 厶は, ある意味現行の市街地の住所の表示法に近いものであるが, 新町名は中心市街地から延長される路線以外は新規の道路群の名 前に関連づけられることになっていた。「方針」においては，当 地の大字小字名を組み合わせたものを新町名とするよう変更され た。これは元の土地の来歴を伝えるものとなっており，今日も住 民に親しまれているところである。

昭和 49 年（1974）に決定された「京都市土地区画整理地区内 における町名町界地番整理要綱（新要綱）」では，それまでの路 線式が退けられ街廓式が採られ，町界を道路境界線等永続的な公 共施設に置くこととされた。

「旧要綱」は「新要綱」が決定される相当以前に実効性を失っ ていたことが，「新要綱」の起案文書から読み取れるが，実際の 
事業地区群の町割を観察することで，それらが昭和 20 年代には 使われなくなっていたことが確認できた。「新要綱」で明瞭な特 徵は, 両側町構造の破棄, 町の面積規模と筆数の拡大である。こ こでは, 不動産登記法上の町名地番設定における「町」と, 地域 コミュニティの単位空間としての「まち」とが, 切り離して考え られているように見える。

このことを, 地域コミュニティの軽視といった議論に短絡させ てはならないだろう。街廓式の大きな町であっても, 町内会等の 近隣集団をうまく配置することによって，住民の共助システムを 効果的に構築することは可能だと思われるからである。「町」で はなく，こうしたミクロなレベルで両側町的な配置が行われてい る例は存在しているようである。

とはいえ, 昭和初期の路線式両側町モデル適用地区が，今もな お独特の佇まいをもっていることは確かである。建築や庭といっ た物的な環境を支える形で, 地域の記憶を留める地名や, 京都の 伝統を敷衍した町の配置などを含む「しくみのデザイン」が，「そ の地域らしさ」「場所性」を生み出しているのである。このこと は今後の市街地の設計においても示唆するところがあるように思 われる。

文書 1 「整理後の町界町名地番設定（方針の部）」 昭和 6 年（1931）「大京都の都市計画に就て」所収

一, 町界町名

(1)町割の方式

路線式を原則とし必要あるときは街廊式又は結合式を併用するあのとす

（註）路線式とは街路に沿ふ建築敷地を以て町を構成するもの 街廓式とは一又は二以上の街廓を以て町を構成するもの 結合式とは路線式を加味したる街廊式にして主要街路を挟みて並列 する街廓の集団を以て構成するむの

(2)町割

一, 南部及び北部に於ては町の形は南北に長き短冊形とす

一, 東部及び西部に於ては町の形は東西に長き短冊形とす 但し四條七條の如き大通りは商店街を形成する関係上短冊形を細く しそれ以外のものは巾廣きむのとす

一，曲折又は形状その他特殊の事情ある個所は可成不変的地物を境とし (理由) て之れを定むるものとす。

，路線式は通信訪問を便利にし修交関係公同自治関係等に於ても他の 方式よりは比較的効果多し

一，新市街は概して大通り又は旧市内に連絡ある通りを中心として発展 する傾向あるを以て町割む大通り又は此等の通りを中心として作る 必要あり

一，路線式によれば街路名之町名とを一致せしめ依て町名のみにて其所 在位置をむ判然せしむることを得

一，新市街に於ける街路名を旧市のそれ等と連絡統一するため

一, 旧市の町割は路線式を以て成る可く京都旧来の伝統を尊ひ旧市との 町割の連絡を取るため

(3)町面積

一，住宅地商業地に於ては三ブロツクに相当する面積約五千四百场 (一万七千七百平方米) と导

工業地に於ては七千坪 (二万三千百四十平方米) 乃至一万坪 (三万三千六十平方米) とす

(理由)

旧市内に於ける一町面積は二千坪 (六千六百十平方米)乃至三千坪 (一万平方米)にして此の町面積の余りに小なりし為町名数多く複雑を 極め町名は通信，訪問等に際し殆んぞ存在の意義を認めざりき。惟ふ に町面積は都市の自治生活最小単位の外形的規範を形成する所の重大 要素なるを以て新市街に於ては旧市街に於けるが如き不便を除くため 更に町としての権威を失隊せしめざらんがために町面積を拡大し百戸 ( 戸約五十坪乃至百坪当り，但し工業地に於ては七十坪乃至百五十坪） 前後を以て一町となすを適当と認む

(4)町区域

一, 東及西の町界は南北に南及北の町界は東西にブロックの中央を縦貫 する線に近き換地筆界線又は適当地番設定線を以て町の境界線とす

一，南部及北部に於ては原則として一䇢町内に南北の道路一條と東西の 道路三條とを含ましむるものとし先ずブロツクの中央を南北に縦貫 する線により各ブロックを半截し斯くして生じたる南北に通ずる道 路の両側に二筒ず相対する半ブロツクと南北両端に一箇ず相対する
四分の一ブロツクとの一団（結局半ブロック四筒四分の一ブロック 四筒合計三ブロツクよりなる)を以て町の基本区域とす

一，東部及西部に於ては先ず一筒町内に東西の道路二條と南北の道路二 条乃至三条を含ましめ東西道路の両外側のブロツクの中央を東西に 縦貫する線と南北道路の両外側のブロツクの中央を縦貫する南北線 とによりて成れる区域を以て町の基本区域とす

（註）結合式或は街廓式に於て道路河川を以て町界とする場合には其の中 理由） 心線を以て町の境界線とす

旧市内の町界は東西か南北かの一方だけが中間線により，他の一方は 街路又は一ロツトをとりて町界となす。然るに新市街に於ては旧市方 式の如く一ロットを取ることは偶々出来得るとするむ概して空地多きた め之れが利用不確定なる関係上町区域を複雑化せしむるを以てブロツ 名の中間線を取るを適当と認む

(5)町名

一，南部及北部方面に於ては南北の道路名を先に呼び東西の道路中，中 央にあるもの名を後に附したるむのを以て町名となす

而して北部に於ける第一号線以北の町名には北と云ふ字を冠し南部 に於ける第三号線以南の町名には南と云ふ字を冠す

一, 東部及西部方面に於ては東西の道路名を先きに呼び南北の道路中中 央にあるむの名を其の後に附したるむのを以て町名となす 而して東部に於ける第一号線以東の町名には東と云ふ字を冠し西部 に於ける第一号線及三号線以西の町名には西之云ふ字を冠す

一，都市計画第一,三,四号事業路線の如き主要街路に該当する個所の町 名は主要道路名を先に呼び其の交叉する中央道路名を後に付したる ものを以て町名とす．但し主要街路が交叉する個所の町名は前項に 依る

一, 第十調查区即ち鹿ヶ谷, 浄土寺方面及曲折変形其の他の事情に依り 必ずしも前二項の方針に寄り難き個所は該方針の精神に其地方の旧 (理由) 名或は史蹟等を考究加味し適当なる町名を附するものとす

旧市の町名の如く町名の上に何々通，何通上る下るを冠するは圥長に 失するのみならず外来者通信其他公称する場合等に於て不便不利少な からず，然るにこの町名方式は通名と町名とを完全に一致せしむる為， 東西, 南北の幹線道路と他の道路との交叉点を利用して町名を取入れ たるを以て幹線道路名は全部そのま〉町名の一部となり直ちにその区 域を知り得るのみならず，道路名をそのま >保存することによりて商 店街としても京都市旧来の傅統と特徴を維持し，一面町名の複雑化を 防ぐことを得るなり

(6) 街路名

東西南北の主要道路及各町の中央を貫通する道路には公称名を附しこ れ等は町名の内容ともなる, 其他の通りは何上 (北) 通何下 (南)通, 又は何西通, 何東通（例へば紫野上通，紫野北通，紫野下通，又は紫 野南通) と呼ばしむるも, この通名は通称に止め公称として用ひざるも のとす

(理由)

新市街に於ても旧市と同じく街路名即ち通り名を用ふる習慣あり, 又 道路管理上に於ても重要なるものには通り名を附するの便利なるを認 む

二, 地番

(1)一箇の地番の面積は五十坪乃至百坪を標準とし，一ヶ町内の地番の数は 百番以内之す

(2)地番設定線は成可く換地筆界を利用し若しこれを利用し得ざる場合は適 当に地番設定線を設けて分割す

（3）地番の起点は旧京都市を中心として町の進路の方向に走る主要街路（東 部，西部に於て東西街路二筋以上ある場合は其の最南方の分)に沿ふ, 左 側の最初の隅角の筆地を以てす

而して左側を若番とし右側を老番とし地番進行方式は「通し戸別番地式 とす

（引用者注：「綱要」に見える「但し書き」は見えず）

(4)地番は一筒町毎に更新せしむ

(5)町割の関係上同一町内に異なりたる整理地区ある場合は他の地区の予定 地番割をなし暫定的に欠番となし整理するものとす

（引用者注：「網要」に見える「註」は見えず）

(理由)

地番方式と町割との相互作用を活用することによつてあらゆる機能を調 和せしむることは町名地番整理の重大要楔なり

旧市街の地番方式は元の組毎に地番を更新せしめ起点を東西隅に置き, 区域中最も西部にある南北の通りを北より南に向つて街路の両側に沿ふ 筆地を千鳥式に縫ひて進み, 第一の通りを終れば次の南北街路を南より 北に復り順次第二第四の街路を往復して最東端の街路に終るむのにして, 地番は六百番以上千番近くに上り徒らに機械的に数字を羅列したるのみ にて毫も能率的なる所な々，単に税務及び戸籍官庁に於ける事務上の必 要を充し居るに過ぎず

故に新市街に於ては町割と地番方式との密接なる関係を考慮し一層実用 的価值を発揮せしむるため新しき地番方式を定めんとするなり 
三，町界町名の標示

町界及辻角に町界町名の標示をなす

(理由)

旧市街に於ても既に各町の要所々々に仁丹製薬会社の町名標示板を用ひ つ〉あるも，本案の如く新市街がブロツクの中心線により町界を定むる 場合に於ては斯くの如き標示方法は特に必要なりとす

四，学区界及公同組合関係は地方的に区々なる事情ありて，複雑なる関係 を生ずるを以て特に基本的方針を樹立せず施行に当り具体的諸事情を卙 酌し適当に解決すること

（引用者注：傍線は，文書 $2 「$ 綱要」との差異が見られる箇所）

文書 2 「京都市区画整理地区二於ケル町界町名地番整理方針 綱要」昭和 6 年 (1931)

一, 町界町名

(1)町割ノ方式

路線式ヨ原則トシさムヨ得ザルトキハ街廊式又八結合式ヨ併用スルモノ トス

（註）路線式卜ハ街路二沿フ建築敷地 街廓式卜ハ一又八一以上ノ街廓ヨ以テ町习構成スルモ 結合式卜八路線式 7 加味シタル街廊式ニシテ主要街路ヨ挟ミテ並列 スル街廓ノ集団ヨ以テ構成スルモノ

(2)町割

，南部及ビ北部二於テハ町ノ形八南北二長キ短冊形卜ス

一，東部及ビ西部二於テ八町ノ形八東西二長キ短冊形卜ス

但シ四條七條ノ如キ大通リ八商店街 7 形成スル関係上短冊形 シソレ以外ノモノハ巾廣キモノトス

一，曲折又は形状ソノ他特殊ノ事情アル個所八可成不変的地物を境卜シ テ之レヨ定ムルモノトス。

(理由)

一，路線式八通信訪問 7 便利ニシ修交関係公同自治関係等二於テモ他ノ 方式ヨリ八比較的効果多シ

一，新市街八概シテ大通リ又八旧市内二連絡アル通リヨ中心トシテ発展 スル傾向アルヨ以テ町割モ大通リ又ハ此等ノ通リ 必要アリ

一，路線式ニヨレバ街路名卜町名トヨ一致セシメ依テ町名ノミニテ其ノ 所在位置ヨモ判然セシムルコトヨ得

一，新市街二於ケル街路名ヨ旧市ノソレ等卜連絡統一スルタメ

一，旧市ノ町割八路線式ヨ以テ成へク京都旧来ノ伝統习尊七旧市卜ノ町 割ノ連絡ヨ取ルタメ

(3)町面積

一, 住宅地商業地二於テハ三街廓二相当スル面積約五千四百坪 (一万七千七百平方米) 卜ス

工業地二於テ八七千坪（二万三千百四十平方米）乃至一万坪 (理由) (三三千六十平方米) トス

旧市内二於ヶル一町面積八二千坪（六千六百十平方米）乃至三千坪 (一万平方米)二シテ此ノ町面積ノ余リニ小ナリシ為町名数多ク複雑 $ᄏ$ 極メ町名八通信訪問等二際シ殆ド存在の意義ヨ認メザリキ. 惟フ二町 面積八都市ノ自治生活最小単位ノ外形的規範习形成スル所ノ重大要素 ナルヨ以テ新市街二於テ八旧市街二於ケルガ如キ不便ヨ除クタメ更二 町トシテノ権威ヨ失墜セシメザランガタメ二町面積ヨ拡大シ百筆 (一 筆約五十坪乃至百坪当リ但シ工業地二於テ八七十坪乃至百五十坪)前 後ヨ以テ一町トナス

(4)町区域

一，東及ビ西ノ町界八南北二南及ビ北ノ町界八東西二街廓ノ中央 7 縦貫 スル線二近キ換地筆界線又八適当地番設定線

一, 南部及ビ北部二於テハ原則トシテ一䇢町内二南北ノ道路一條卜東西 ノ道路三條トヨ含マシムルモノトシ先ヅ街廓ノ中央 7 南北二縦貫ス ル線ニヨリ各街廓ヨ半截シ斯クシテ生ジタル南北二通ズル道路ノ両 側二二箇ヅ 相対スル半街廓卜南北両端二一箇ヅ 相対する四分ノ 一街廓卜ノ一團（結局半街廓四箇四分ノ一街廓四箇合計三街廓ヨリ ナル)ヨ以テ町ノ基本区域卜ス

一, 東部及ビ西部二於テハ先ヅ一箇町内二東西ノ道路二條卜南北ノ道路 二条乃至三条 7 含マシメ東西道路ノ両外側ノ街廓ノ中央 $\exists$ 東西二縦 貫スル線卜南北道路ノ両外側ノ街邡ノ中央 7 縦貫スル南北線卜ニヨ リテ成レル区域

（註）結合式或は街廓式二於テ道路河川 心線ヨ以テ町ノ境界線卜ス

(理由)

旧市内ノ町界八東西力南北力ノ一方ダケガ中間線ニヨリ他ノ一方八街 路又ハ一ロットヨトリテ町界トナス然ルニ新市街二於テハ旧市方式ノ 如ク一ロットヨ取ルコトハ偶々出来得ルトスルモ概シテ空地多キタメ
之レガ利用不確定ナル関係上町区域ヨ複雑化セシムルヨ以テ街廓ノ中 間線ヨ取ルヨ適当卜認ム

(5)町名

一，南部及北部方面二於テ八南北ノ道路名 7 先二呼ビ東西ノ道路中，中 央ニアルモノ〉名 而シテ北部二於ケル为一号線以北ノ町名二八「北」ノ字习冠シ南部 二於ヶル为一号線及三号線以南ノ町名二八「南」字を冠又

一，東部及西部方面二於テ八東西八道路名ヨ先キ二呼ビ南北八道路中中 央ニアルモノ〉名ヨ其ノ後二附シタルモノヨ以テ町名トナス 而シテ東部二於ケル为一号線以東ノ町名二ハ「東」ノ字 7 冠シ西部 二於ケル为三号線以西ノ町名二八「西」ノ字を冠又

一，都市計画为一, 三,四号事業路線ノ如キ主要街路二該当スル個所ノ町 名八主要道路名 $习$ 先二呼ビ其ノ交叉スル中央道路名 7 後二付シタル モノヨ以テ町名卜ス但し主要街路ガ交叉スル個所ノ町名八前項二依 ル

一, 为十調查区即千鹿ヶ谷, 浄土寺方面及ビ曲折変形其ノ他ノ事情二依 リ必ズシモ前二項ノ方針二寄リ難キ個所八該方針ノ精神二其地方ノ 旧名或八史蹟等习考究加味シ適当ナル町名

(理由)

旧市ノ町名ノ如ク町名ノ上二何々通何通上ル下ルョ冠スルハて長二失 スルノミナラズ外来者通信其他公称スル場合等二於テ不便不利少ナカ ラズ然ルニコノ町名方式八通名卜町名トヨ完全二一致セシムル為東西 南北ノ幹線道路卜他ノ道路卜ノ交叉点 $コ$ 利用シテ町名 $\exists$ 取入レタル 以テ幹線道路名ハ全部ソノマ>町名ノ一部トナリ直チニソノ区域 リ得ルノミナラズ道路名ヨソノマ〉保存スルコトニヨリテ商店街トシテ モ京都市旧来ノ傅統卜特徵ヨ維持シ, 一面町名ノ (判読不能一字)語 化ヨ防グコトヨ得ルナリ

(6) 街路名

東西南北ノ主要道路及ビ各町ノ中央习貫通スル道路二八公称名 コレ等八町名ノ内容トモナル，其他ノ通リ八何(北)通何 (南)通, 又 八何西通何東通 (例へバ紫野北通又八紫野南通) ト呼バシムルモコ) (理由) 通名ハ通称ニ止メ公称トシテ用ヒザルモノトス

新市街二於テモ旧市ト同ジク街路名即チ通リ名ヨ用フル習慣アリ，又 道路管理上二於テモ重要ナルモノニハ通リ名ヨ附スルノ便利ナル 認 厶

二, 地番

(1)一箇ノ地番ノ面積八五十坪乃至百坪 7 標準トシ一箇町内ノ地番ノ数ハ百 番以内卜ス

(2)地番設定線ハ成ベク換地筆界 当二地番設定線ヨ設ケテ分割ス

(3)地番ノ起点八旧京都市 部, 西部二於テ東西街路二條以上アル場合八其ノ最南方ノ分)二沿フ左 側ノ最初ノ隅角ノ筆地 $\exists$ 以テス

而シテ左側ヨ若番トシ右側ヨ老番トシ地番進行方式八「通シ戸別番地式 トス

但シ小面積ノモノ八隣地ノ枝番

(4)地番八一筒町毎二更新セシム

(5)町割ノ関係上同一町内二異ナリタル整理地区アル場合八他ノ地区ノ予定 地番割ヨナシ暫定的ニ欠番トナシ整理スルモノトス (註)

耕地整理地区取扱手続为四條二八梢抵觸スル如キ嫌アルモ永久二訣番卜 ナルニ非ザレバ周囲ノ整理完成ノ暁ハ却テ便宜卜認ム

(理由)

地番方式卜町割卜ノ相互作用ヨ活用スルコトニ依ツテアラユル機能 和セシムルコトハ町名地番整理ノ重大要楔ナリ

旧市街ノ地番方式ハ元ノ組毎二地番 域中最モ西部ニアル南北ノ通リ $ヨ$ 北ヨリ南二向ツテ街路ノ両側二沿フ筆 地ヨ千鳥式二縫ヒテ進ミ为一ノ通リヨ終レバ次ノ南北街路ヨ, 南ヨリ北 二復リ順次为三为四ノ街路 7 往復シテ最東端ノ街路二終ルモノニシテ地 番八六百番以上千番近ク二上リ徒ラニ機械的二数字 羅列シタルノミニ テ毫モ能率的ナル所ナシ

故二新市街二於テハ町割卜地番方式卜ノ密接ナル関係ヨ考慮シ一層実用 的価值ヨ発揮セシムルタメ新シキ地番方式ヨ定メントスルナリ

三，町界町名の標示

町界及辻角二町界町名ノ標示ヨナス

(理由)

旧市街二於テモ既二各町ノ要所々々二仁丹製薬会社ノ町名標示板 $\ni$ 用七 ツ〉アルモ本案ノ如ク新市街ガブロックノ中心線ニヨリ町界ヨ定ムル場 合二於テハ斯クノ如キ標示方法八特二必要ナリトス

四，学区界及公同組合関係八地方的二区々ナル事情アリテ複雑ナル関係 生ズル シ適当二解決スルコト 
文書 3

「町界町名地番の整理（方針の部）」 昭和 10 年 (1935)「京都土地区画整理事業概要」所収

\section{一, 町界町名}

(1)町割ノ方式

路線式ヨ原則トシさムヨ得ザルトキハ街廓式又ハ結合式ヨ併用スルモノ トス.

(2)町割

一, 町ノ形八南北二長キ短冊型卜ス但シ四條，七條ノ如キ大通八商店街 ヨ形成スル関係上東西二長キ短冊型卜ス。

一, 曲折又八形状其ノ他特殊ノ事情アル個所八可成固定的地物 テ之レヨ定ムルモノトス.

(3)町面積

三街廓二相当スル面積五千四百坪内外 標準トス.

(4)町区域

一, 原則トシテハ一箇町内二南北ノ道路一條卜東西ノ道路三條 ムルモノトシ, 先ズ街廓ノ中央 7 南北二縦貫スル線ニヨリ各街廓 半裁シ斯クシテ生ジタル南北二通ヅル道路ノ両側二二筒ヅ〉相対ス ル半街廓南北雨端二一䇢ヅ 相対スル四分ノ一街廓卜ノ一団（結局 半街廓四箇四分ノ一街廓四箇合計三街廓ヨリナル) ヨ以テ町ノ基本 区域卜ス。

（註）結合式或八街廓式二於テ道路河川ヨ以テ町界トスル場合二八其ノ中 心線 以テ町ノ境界線トス.

(5)町名

一, 先ズ従来ノ大字名 7 冠シ旧来ノ小字名 尊重不更二是等ノ小字名ノ 上二東，西，南，北，上，下，等ノ字 7 冠シテ用フルコトアリ。但 シ読ミ難キモノ書キ難キモノ，語呂ノ悪キモノ又ハ感ジ悪キモノ八 捨ツルコトトス. 新町名ヨ付スル場合二八当地方二関係アル歴史又 八地理二関スル町名 7 附シ尚之二依リ難キ場合二八佳名ヨ附スルコ トアルベシ.

(6) 街路名

一, 東西, 南北ノ主要街路二八, 道路名ヨ付シ，之レ等二平行スル，左 右, 上, 下ノモノニ八，東，西，南，北，ノ字ヨ冠スルコトアリ。但 シ旧市ヨリノ延長ノモノニ八，在来ノ道路名ヨ用フ

二, 地番

(1) 一箇ノ地番ノ大キサハ百坪内外 標準トシ一箇町内ノ地番ノ数八百番以 内卜ス。

(2)地番設定線ハナルベク換地筆界 八適当二地番設定線习設ケテ分割ス。

(3)地番ノ起点八町ノ中央 7 南北二走ル主要街路二沿フ左側ノ最初ノ隅角ノ 筆地ヨ以テス。面シテ左側 若番卜シ右側ヨ老番卜シ地番進行方式八「通 シ戸別番地式 $」$ 卜

(4)地番八一筒町毎二更新セシム

(5)町割ノ関係上同一町内二異ナリタル整理地区アル場合八他ノ地区ノ予定 地番割ヨナシ暫定的二欠番トナシ整理スルモノトス.

三，町界町名ノ標示

町界及び辻角二町界町名ノ標示ヨナス。

文書 4 「(旧) 京都市土地区画整理地区内における町名町界地 番整理要綱」昭和 6 年 (1931)（疑問あり）

1 町界 町名

1 町割の方式

路線式を原則としてやむをえない時は, 街かく式又は結合式を併用す るものとする。

2 町割

1 町の形は南北に長き短冊型とする。 ただし，四条七条の如き大通

りは商店街を形成する関係上, 東西に長き短冊型とする.

2 曲折又は形状，その他特殊の事情ある個所は，なるべく固定的地 物を境として，これを定めるものとする。

3 町面積

三街路（原文ママ「廓」の誤記と思われる）に相当する面積 5,400 坪 内外を標準とする

4 町区域

1 原則としては 1 個町内に南北の道路 1 条と東西の道路 3 条を含ま しむるものとして, 先ず街かくの中央を南北に縦貫する線により各

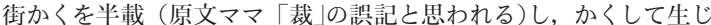
たる南北に通じたる道路の両側に 2 個づつ相対する半街かくと南北 両端に 1 個づつ相対する 4 分の 1 街かくとの一団（結局半街かく 4 個,
4 分の 1 街かく 4 個, 合計 3 街かくよりなる)を以って町の基本区域 とする

（注，結合式あるいは街かく式において道路河川をもって町界とする場合 には，その中心線をもって町の境界線とする.）

5 町名

1 先ず従来の大字名を冠し, 旧来の小字名を尊重する. 更にこれら の小字名の上に東, 西, 南, 北, 上, 下, 等の字を冠して用いるこ とがある、ただし，読み難いもの，書き難いもの，語呂の悪いもの 又は感じ悪いものは捨てるものとする. 新町名を付する場合には, 当地方に関係ある歴史又は地理に関する町名を附して, なおこれに より難い場合には佳名を附することがある。

6 街路名

東西南北の主要街路には佳名を附し，これ等に平行する左右上下のむ のには東西南北の字を冠することがある、ただし，旧市より延長のもの には在来の道路名を用いる.

2 地番

11 個の地番の大きさは 100 坪内外を標準として 1 個町内の地番の数 は 100 番内外とする。

2 地番設定線はなるべく換地筆界を利用する，若しこれを利用できな い場合には適当に地番設定線を設けて分割する。

3 地番の起点は町の中央を南北に走る主要街路に沿う左側の最初の隅 角の筆地をむってする．面して左側を若番として地番進行方式は「通 し戸別番地式」とする。

4 地番は 1 個町毎に更新せしめる。

5 町割の関係上同一町内に異なった整理地区がある場合には他の地区 の予定地番割をなし暫定的に欠番となし整理する。

3 町界町名の標示

町界及び辻角に町界町名の標示をする.

文書 5 「京都市土地区画整理地区内における町名町界地番整 理要綱」昭和 49 年 (1974)

\section{(趣旨)}

第 1 この要綱は，本市区域内において施行する土地区画整理事業の施行 地区（以下「施行地区」という.）内における町名町界および地番の整理（以 下「整理」という.)について必要な事項を定めるものとする.

(整理区域)

第 2 整理の対象となる区域は，施行地区内とするものとする．ただし， 現地の状況により一部施行地区外におよぶことがある。

(町の形状)

第 3 町の形状は，境界が複雑とならず，かつ飛び地が生じないよう簡明 な境界線をむって区画されたおおむね四角形の一団をむって形成するもの とする.

(町の大きさ)

第 4 町の大きさは，用途地域抢よび町の性格，並びに通学区域，将来の 発展性等を考慮して定めるものとする。この場合において標準となる町の 大きさは，別表に掲げるところによるものとする.

(町割りの方式)

第 5 町割りの方式は，街区方式によるものとする。

ただし，現地の状況により，これにより難い場合においては，他の方式 によることができるものとする.

2 前項中「街区方式」とは，认くつかの街区をもって組織する町割方式で あり，町界は道路河川等恒久施設によるものをいう。

(町の境界)

第6 町の境界は，道路，河川，水路，鉄道等（以下「公共斾設等」という。） 恒久的な施設をむって定めるものとする．ただし，現地の状況によりこれに より難い場合においては，筆界線等をむって定めることができるものとする.

(町の境界線)

第 7 町の境界線は, 公共施設等の側線をむって定めるものとする. この場合において，町界が東西線の場合は，南側，南北線の場合は東側 の各々側線とするものとし，地区界線が公共施設等の北側および西側に設 けられているなど現地の状況により, これにより難い場合においては, 他の 方法により定めることができるものとする.

(町の名称)

第 8 町の名称は，従来の名称を尊重することを基本とし，次の各号に定 めるところによるものとする.

1 歴史上由緒ある名称, 親しみ深い名称およびわかりやすい名称を用いる. 2 市内で同じ名称执びこれに類似したまぎらわしい名称または読みにく 
|い名称は, 原則として用いない.

3 従来の町を分割する場合においては，従来の名称に東西南北等の字を 冠して用いる。

4 整理区画内の住民およびその他の関係者から意見要望等を十分聴聞する

(地番)

第 9 地番の設定については, 不動産登記法第 79 条により管轄登記所が 定められることとされているが，地番の整理は，原則として次の各号に定 めるところによるものとする

1 地番区域は 1 個町を単位とする。

2 地番区域毎に起番し, 土地 1 筆毎に地番を付するものとし, 原則とし て支番は用いない

3 地番の起点は, 町の西北隅とし, 各街区の西北隅より右まわりで設定し, 地番が連続するように考慮する。

4 公道，河川，公有水路等については，宅地の地番とまぎらわしくない よう 3 桁の地番に支番を付して用いる．例えば，地番区域の最終地番が 120 番となっている場合には 121 番以降を欠番とし, 公道を 200 番, 公有水路 を 300 と定め, 各々の地番に支番を付して用いるものとする.

(別表)

（面積の単位 平方メートル）

\begin{tabular}{|c|c|c|}
\hline 地 域 別 & 面 積 & 筆数 \\
\hline 商業を主とする地域 & 25,000 & 250 筆 \\
\hline 住居を主とする地域 & 30,000 & 200 筆 \\
\hline 工業を主とする地域 & 50,000 & 100 筆 \\
\hline
\end{tabular}

付則

(施行期日)

1 この要綱は昭和＼cjkstart年月日から施行する。

(旧要綱の廃止)

2 京都市土地区画整理地区内における町名町界地番整理要網は廃止する.

文書 6 「整理後の町界町名地番設定（経緯の部）」 昭和 6 年 (1931)「大京都の都市計画に就て」所収

次に区画整理後の町界町名地番の新設は, 所謂換地処分と共に本事業の 画龍点睛とも云ふべき重要な一項目であるが，本市の広范たる土地区画整 理区域に対して統一的な町界町名地番設定の必要上，且つ又各地区の沿革 を稽へその固有の伝統を保持しつ〉新京都に相応しき名称を選定せんとす 趣旨に基き，本市は町界町名地番設定調査委員会を設けた。即ち昨年十一 月斯界の権威たる京大教授西田直二郎，石橋五郎両博士，郷土史家猪熊淺 麿，出雲路通次郎氏等を該委員に嘱託し調査審議を重的る事十数回，其第 一次調査としては東は賀茂街道, 西は大徳寺通, 北は旧市郡境, 南は疏水 を境とする五十余万坪の区域に対し此程成案を見るに至つたので，関係諸 組合中よりも委員を選任し，聯合協議会を開いて具体案決定の後，不市市 へ禀議する事となつている. 今後工事完成の地区毎に逐次新町名が市民諸 君に相見えるであらう

\section{文書 7 「町界町名地番の整理（経緯の部）」}

昭和 10 年（1935）「京都土地区画整理事業概要」所収

区画整理二伴ヒ町界町名地番ノ整理ノ必要ヨ生ジタル ヨ確定センガタメ昭和五年十一月二十六日京都帝大教授其ノ他故事二通暁 セル識者二嘱託シ，町界町名地番二関スル協議会习開キ昭和六年三月マデ 二協議会ヨ開クコト八回二及ビ『京都市区画整理地区内二於ケル町界町名 地番整理方針綱要』ヨ決定シ右方針二基キ『賀茂第一, 第二, 上堀川, 紫 竹芝本，紫野門前，東紫野組合地区二於ケル設定案』ᄏ決定シ同六年十二 月二十二日第九回ノ協議会二於テ修正ス．昭和七年十月二及ビテ『北部区 画整理区域町界町名地番設定調査連合委員会』习設置シ関係組合ノ委員二 ヨリテ三回二亘リ協議シタル結果前協議会ノ終正案ヨ更二修正シタル上昭 和十年一月十五日市会二於テ，「賀茂第一，第二上堀川，紫竹芝本，紫野 門前, 東紫野, 西紫野」各組合ノ町界町名決定セラレタリ。右町界町名地番 整理方針ハ次ノ如シ

\section{文書 8 「京都市土地区画整理地区内における町名町界地番整 理要綱の改正について」 昭和 49 年 (1974)}

(説明)

土地区画整理事業においては，土地の区画形質の変更および公共施設の 新設, 又は変更が行なわれる為，必然的に町名町界地番の整理が生じてくる。 新しい街かくによって構成された市街地は，これを適正に区域づけること により，初めて健全な宅地としての利用ができるということがいえる.

換言すれば，区画整理事業の目的がここにおいて完成されるといっても 過言ではないと考える。この意味において，町名町界地番整理について慎
重かつ適正な整理が必要とされるのである。

このため，京都市においては，昭和 6 年 3 月決定の「京都市土地区画整 理地区内における町名地番整理要綱 \があるが，時代の推移に伴い，実情に 沿わない面がでてきており, 現在ほとんど適用されず「住居表示に関する 法律」等を参考にしているのが現状である。

これがため，今回現況に適するよう内容全般にわたり再検討を加え，整 理の適正化を計るべく全面改正を行なおうとするものである。

謝辞

京都市建設局都市整備部市街地整備課には，資料の閲覧等にお いてご配慮をいただいた。立命館大学大学院文学研究科の飯塚隆 藤氏には，街区形状の分析等においてさまざまなアドバイスをい ただいた。ここに厚くお礼申し上げます。

\section{補注及び引用文献}

1 ) 中川理 (2008): 都市計画事業として実施された土地区画整理 : 近代京 都研究, 52-85, 思文閣出版 など

2 ) 鶴田佳子・佐藤圭二 (1994): 近代都市計画初期における京都市の市街 地開発に関する研究 : 日本建築学会計画系論文集 (458),99-108

3 ) 鶴田佳子・佐藤圭二 (1992): 宅地開発型耕地整理事業の設計水準の発 展過程に関する研究一名古屋市の場合 : 日本都市計画学会学術研究論 文集 $(27), 43-48$

4 ）㘧正浩・川上光彦: 土地区画整理事業の計画設計標準の変遷とその適 用一金沢市に打ける事例研究一: 日本都市計画学会学術研究論文集 (34), 127-132

5 ) インターネットで公開されている PDF 版新要綱においては，附則（旧 要綱の廃止）において「京都市土地区画整理地域内における町名町番 整理要綱は廃止する（2013 年 11 月 18 日閲覧)」とされており，担当 課より提供されたものとは文書名に相違が見られるが，本稿において は，これはネット上に置く際に生じた䛊記であると判断した。

6 ) 京都の歴史的な市街地では，他に見られない特異な方法で住所を表示 する。これは 2 つ直交する道路を並べて交差点を示し，そこから「上 る」「下る」「東入る」「西入る」等を付けて交差点からの方向を示し た上で，町名と番地を付すというものである。道路名の順は，当該住 所が面する道路を先にする。通り名と町名を並べるのは，市内に同じ 名を持つ町が多数存在するためといわれる。京都市は政令指定都市で 唯一住居表示を導入しておらず，この住所は不動産登記法上の地番と して使われる。この原則によれば京都市役所の住所は「京都市中京区 寺町通御池上る上本能寺前町 488 番」となる。ちなみに南第三土地区 画整理事業地内にある京都市上下水道局の住所は「京都市南区東九条 東山王町 12 番地」であり，通り名を欠き「東九条（大字名に相当）」 「東山王 (小字名に相当)」の組み合わせとなっている。

7 ) 町区域を $\lceil 1 / 2$ 街廓」 4 つと $「 1 / 4$ 街廓」 4 つ（合計 3 街廓相当）か らなる図－3 のモデルとし，そこに 200 筆を組み込もうとすると，「1/2 街廓」部分に 32 筆程度,「1/4 街廓」部分に 16 筆を収める（合計 192 筆) こととなり，街区が極端に東西に長くなってしまう。これを避け るには，街区の南北長を増し内部に路地や端笔型の宅地を設けること が考えられるが，これは「綱要」で示されたような路線式の美点を損 なうものである。

8 ) 路線式両側町モデルは, 既存建築物のあまりない農村地帯に新しく街 を建設する際には特に問題なく援用できたようである。「京都土地区 画整理事業概要」に収められた事業誌を見ていくと（賀茂，上堀川， 紫竹芝本，紫野門前，平井高原など）早期に施行された洛北地域での 事業は，農村地帯でありながらスプロールが予想される地域で先手を 打って施行されたものが多い。しかし既存建物の密集した地区（南第 二など）では，そうしたモデルを適用していくことには困難があった むのと思われる。例えば平井高原においては「…土地ノ区画亦頗ル不 規則ニシテ利用価值甚ダ少カリキ，然ルニ土地高燥ナル上風景又佳ナ ル ツ以テ近時住宅地トシテ家屋ヨ新築スルモノ相継デ起リ漸次市街化 シッ〉アル状態ナリ．計画ノ大要八理想的住宅地タラシムル ノ目標トシ…とある一方, 南第二地区では, 密集した既存建物群に ついての「遺憾」との記述が見られる。

9 ）高度成長期には，市南部を中心に工業団地の造成を目的とした土地区 画整理事業が施行されるが，これらは大規模な画地を有するもので路 線式両側町モデルは当然ながら援用されていない。

(2014.1.24 受付，2014.8.23 受理) 